\title{
O professor se perde a face ${ }^{1}$
}

\author{
Núbio Delanne Ferraz Mafra²
}

\begin{abstract}
RESUMO
Tão importante quanto os fatores conjunturais que têm contribuído para a crescente proletarização docente, muitas atitudes e concepções do próprio próprio professor costumam colaborar com este processo, automatizando e descaracterizando sua prática pedagógica.
\end{abstract}

Palavras-chave: proletarização do professor, competência técnica, massificação do ensino, identidade profissional

O memorialista Pedro Nava acreditava ser a experiência igual aos faróis invertidos de um carro - só serviriam para iluminar o que já passou. De certa forma, como ele, encaro com certo desconforto a situação de tentar transmitir minha experiência para vocês. A princípio, minha vivência no magistério reveste-se de determinadas particularidades que talvez não preencham nem meia página de um romance de quinta categoria.

Sem serem desprezíveis - odeio as falsas modéstias -, minhas experiências são fotografias de um homem comum, professor comum, que gosta de um bom dedo de prosa. Seja ela com um colega de trabalho, um aluno ou um companheiro de copo.

Mesmo tendo trabalhado durante 12 anos como professor de Língua Portuguesa e Literatura no $1^{\circ}$ e $2^{\circ}$ graus, em escolas públicas ou particulares, acredito que o principal motivo do convite tenha surgido por ter trabalhado em duas realidades bastante distantes para a maioria dos presentes: Minas Gerais e Rio de Janeiro.

Meus três meses de Paraná já me permitem ousar afirmar que as reali-

\footnotetext{
${ }^{1}$ Texto apresentado na mesa-redonda "Prática de Leitura e Produção de Textos na Escola", Encontro de Professores de Língua Portuguesa e Literatura com alunos do Curso de Letras da UEPG. Ponta Grossa (PR), 29/6/98.

${ }^{2}$ Mestre em Educação pela UFF, Professor de Metodologia e Prática de Ensino de Português da UEPG.

Olhar de professor, Ponta Grossa, 1(1):25-28, out. 1998.
} 
dades de Minas e do Rio talvez sejam distantes, mas não tão diferentes das observadas aqui. Igualá-las seria, todavia, um risco e uma precariedade. Obviamente há diferenças entre os três estados, mas minhas colocações buscarão enfatizar um aspecto que é comum a todos eles e, em termos gerais, à educação, porque fala de uma angústia (dentre muitas) do acadêmico em final de curso. Afinal, ainda vale à pena ser professor?

\section{$* * * * *$}

A desvalorização do papel do professor tem levado à sua crescente proletarização. Como o operário que aperta um parafuso mecanicamente todos os dias, aqui entendemos como proletário aquele que não detém o controle sobre o que produz, transformando-se num mero reprodutor.

Muito se discute os fatores conjunturais que têm favorecido esta proletarização. Partindo-se da formação social e política dos professores, é possível se classificar um segmento como atuando no magistério por opção; outro, por falta de opção; e um terceiro, por falta do que fazer. Os primeiros são cada vez mais raros...

Geraldi, discutindo a proletarização do magistério sob a ótica de diferentes relações de trabalho, afirma que

Ao diplomar seus professores, dando-os como habilitados (penso aqui naqueles com formação universitária), o sistema lhes diz que são profissionais. Depois, contrata-os e trata-os como não profissionais ao longo do exercicio do magistério. E faz isso de vários modos: por uma relação em que os direitos do trabalhador não são respeitados; por condições de trabalho que não the dão sequer espaço físico para continuarem estudando, etc. (GERALDI, 1993, p. XIX).

Pretende-se abordar esta crescente desvalorização levando em conta a particularidade teórico-prática do professor. É um mero recorte na abordagem para fins de exposição que ao final, com certeza, será enriquecido com as observações e questionamentos dos presentes. O educador não será aqui analisado como vítima dos mandos e desmandos do poder, mas como um profissional que, em muitos casos, mais inconsciente do que conscientemente, tem "se proleta-rizado" a partir suas ações e concepções.

Esta autoproletarização, neste caso, não está vinculada diretamente à sua origem social, mas à sua postura pessoal e profissional. Alguns sinais acabam por evidenciar esta postura.

Talvez o principal deles seja a desvinculação da ação pedagógica em relação à ação política. Ora, o ato pedagógico é uma ação política e o professor precisa estar ciente deste fato. $\mathrm{O}$ discurso da neutralidade da ação pedagógica é a máscara do reprodutivismo não compromissado com a transformação. Ingenuamente ou não, este discurso acaba por fazer o jogo político dos que detém e tra- 
balham o poder de forma conservadora. É uma concepção vinculada ao positivismo acreditar-se no intelectual como uma entidade acima e à parte de qualquer questão mundana. Ninguém fica em cima do muro no magistério, ainda que acredite nisto.

Se evitamos o formalismo de tratar o técnico e o político como segmentos estanques e separados, mais uma vez a questão da capacitação profissional do professor e de sua formação cultural mais ampla se coloca com grande relevância. Para a tarefa de ser um dos agentes de mudança da escola e da prática pedagógica visando a tornála mais adequada às crianças que até hoje vêm sendo vítimas do fracasso escolar, o saber fazer técnico constitui condição necessária porque é a base do querer político, ainda que a dimensão política da tarefa não seja percebida como tal (MELLO, 1988, p.141).

Este saber fazer técnico como ferramenta para a transformação política está diretamente ligado à formação acadêmica e cultural do professor. Porém não deve ser compreendido como o mero acúmulo de conhecimentos, mas também, e principalmente, pela capacidade de articular estes conhecimentos a partir de uma metodologia participativa e transformadora do indivíduo e do mundo.

Outro sinal da autoproletarização do professor ocorre muitas vezes na própria relação mantida com o aluno. Muitas vezes inseguro de sua formação, o educador substitui a competência técnica pelos arroubos do senti- mento.

Ao invés de buscar as soluções de eventuais impasses através recursos teóricos e metodológicos de sua disciplina, o professor resvala no sentimentalismo. Ora os alunos, mesmo estando a ponto de serem reprovados, são, apesar de tudo, umas gracinhas; ora eles são a própria encarnação do mal e, como tal, deveriam arder nas chamas do inferno...

Como transformar seus alunos, se ele não consegue nem assumir a necessidade de transformar suas aulas? Se um dia ele conseguisse assumir esta necessidade de transformação, será que se veria em condições de efetuá-la?

(...) no que se refere à prática docente, suponho que o despreparo e a insegurança técnica estão na raiz da dissimulação, da estratégia de culpar a vítima e ao mesmo tempo amá-la sem nada poder fazer de objetivo para evitarlhe o peso do fracasso. Uma melhor capacitação profissional do professor permitira, no mínimo, eliminar essa hipótese. Sem ela, pouco se pode afirmar com segurança acerca de sua disponibilidade e vontade política para mudar a escola. (id. ibid., p. 146)

Um último aspecto aqui abordado refere-se à utilização do livro didático. Este vem cada vez mais assumindo a regência de classe, no lugar do professor - mero executor das ordens do livro. Como um operário frente a um manual de instruções da má- 
quina com a qual vai trabalhar, o professor muitas vezes tem se alienado da necessidade de produzir a sua aula, de impor-se como individualidade, como ser humano marcado por uma trajetória que pode e precisa ser compartilhada com seus alunos.

Sabemos que o ideal seria que ganhássemos bem para que tivéssemos tempo suficiente de planejar nossas próprias aulas. Mas não se trata aqui de desqualificar a presença do livro didático em sala de aula. A questão fundamental é a forma de utilização que se dá aos recursos didáticos. Há aulas profundamente interessantes e provocativas, tendo por base o livro didático, assim como há outras absolutamente originais quanto ao material utilizado, mas medíocres na sua execução e resultado final.

A massificação do ensino, a partir da década de 70 , tem trazido para a sala de aula professores também oriundos dos segmentos populares, dentre os quais me incluo. Sou o sexto filho de um ferroviário. Minha origem provavelmente não é diferente da maioria dos aqui presentes.

Este dado pode ser positivo ou negativo. Depende de nós. A escola constitui-se tradicionalmente como um espaço de transmissão de saberes, cenário de reprodução dos valores da classe dominante. Cabe a nós transformá-la no espaço da modificação. No caso da escola pública, mais do que uma necessidade, é uma obrigação ética e política de todos.

$\mathrm{Na}$ construção deste projeto, um caminho é fundamental. A constituição por parte do professor de uma identidade profissional, ainda que a despeito de toda a "normatização gerencial pedagógica" (GIROUX, 1992) que tem buscado padronizar o ensino, instrumentalizando o professor e descaracterizando o aluno.

A resposta que se deva dar a este estado de coisas é buscarmos a construção de nosso caminho. Responder ao imobilismo com movimento. No lugar da massificação, o respeito à individualidade sustentada no diálogo constante com nossos pares e ímpares. Um diálogo que subentenda atualização constante, seja ela em forma de cursos de reciclagem, discussão com grupos de trabalho, leitura de jornais e revistas, atuação em movimentos da categoria, dentre outros. Fazermos cada um a revolução cotidiana, oculta e silenciosa, construída nas poéticas asperezas da sala de aula.

\section{REFERENNCIAS BIBLIOGRÁFICAS}

1 GERALDI, João Wanderley. Portos de passagem. São Paulo: Martins Fontes, 1993.

2 GIROUX, Henry. Escola crítica e política cultural. Trad. Dagmar M. L. Zibas. 3.ed. São Paulo: Cortez, 1992. (Coleção Polêmicas do Nosso Tempo - 20)

3 MELLO, Guiomar N. de. Magistério de $1^{0}$ grau: da competência técnica ao compromisso político. 9.ed. São Paulo: Cortez, 1988. (Coleção Educação Contemporânea). 